\title{
The Importance of the Danube Strategy for Tourism and Culture Development of the Croatian Danube Region
}

\author{
Demonja DamirA* \\ Received: April 2012 | Revised: June 2012 | Accepted: June 2012
}

\begin{abstract}
The Danube Region consists of various countries that are determined by geographic, economic, cultural and socio-demographic characteristics. Certain regions show different trends of development with increasing regional differences. Regarding that the importance gets newly formed EU Strategy for the Danube Region, the Danube Strategy, which represents a new approach to the European Union's macro-regions, and is focused on four main directions of cooperation in the Danube Region: linking macroregions, environmental protection, building prosperity and strengthening macro-region.

Croatia, as a Danube country, accepted the idea of creating a unified European international space, as suggested in the Danube Strategy, and it is actively engaged in the process. The Croatian Danube Region includes two easternmost counties, Osijek-Baranja and Vukovar-Srijem. The rich cultural and natural heritage of the two counties can be further exploited in the improved tourist offer, advocated by the Strategy. Croatian Danube Region has tourism potentials and with the appropriate measures and incentives this region could become one of the leading regions in continental tourism in Croatia.

This article presents and analyzes the Danube Strategy and its importance for Croatia, the tourist and cultural potentials of the Croatian Danube Region with regard to their greater recognition and utilization as crucial for sustainable development of this, in terms of tourism, still insufficiently developed parts of Croatia, and the possibilities of tourism and culture in the Croatian Danube Region within the framework of the Danube Strategy.
\end{abstract}

Key words: Croatia, Danube Region, Danube Strategy, tourism, culture, potentials

\section{Introduction}

The EU strategy for the Danube Region, the Danube Strategy, represents a new approach to the European macro-region of the Danube basin. It involved 8 member states of the European Union (Germany, Austria, Czech Republic, Slovakia, Slovenia, Hungary, Bulgaria and Romania) and 6 non-member states of the Union and the Danube basin (Croatia, Serbia, Bosnia and Herzegovina, Montenegro, Ukraine and Moldova), a total of 14 countries that have 115 million inhabitants, connected by the Danube River. The Danube Region is characterized by various groups of Danube countries in relation to the integration processes, as well as a number of preconditions and characteristics: geographic, economic, cultural and socio-demographic. Due to the spaciousness of the region, its characteristics and development trends in each country, regional differences are present, and the fundamental purpose of the Strategy is to intensify the relationship between the functional and strategic cooperation which should be achieved. It may be claimed, generally looking, that the Danube Strategy represents an excellent frame-

A Institute for International Relations, IMO, Ljudevita Farkaša Vukotinovića 2, HR-10000 Zagreb, Croatia; e-mail: ddemonja@irmo.hr 
work for the cooperation of member states and countries that are not European Union members.

In this regard, Croatia's place in the Danube Strategy is the realization of new possibilities and potentials for strengthening the economy, regional cooperation and infrastructure development, in which Croatia is committed to proactive participation. The Croatian Danube Region includes two of the easternmost counties, Osijek-Baranja and Vukovar-Srijem, which represent $11.7 \%$ of Croatian territory, where resides $12.1 \%$ of the population, and due to the natural and cultural richness this makes it one of the most important continental tourist areas in Croatia (Fig. 1). Therefore, this paper will analyze the tourism potentials and activities of these two counties. They are crucial because in cooperation with a culture, whose resources will also be presented and analyzed, they can serve as a starting point for further development and affirmation of the Danube identity of Croatia, and the sustainable development of the two counties through the implementation of a number of cross-border and transnational projects and intensification of entrepreneurial activity in the sector of tourism and culture. Furthermore, the goals of improvement and development of tourism and culture in the Danube Strategy are complementary to those of Croatia. Specifical- ly, the Danube Strategy in the areas of tourism and culture offers many opportunities to increase exploitation of transnational and cross-border cooperation programs, which can unleash the entrepreneurial potentials and can be used to "draw" funds from the European Union, which Croatia has already successfully been implementing.

\section{Review of recent research and literature}

Since the activities related to the Danube Strategy and its operational implementation are "in progress", there are a large number of, primarily, documents on the Internet, while the analysis/articles of the Strategy presented at numerous conferences and meetings are mostly unpublished, and can be considered as "gray literature".

However, in Budapest, Hungary, in 2009, "The Blue Ribbon Research Center" (BRRC), was founded and it deals with macro-regional researches along the river Danube, which is one of the themes of the Danube Strategy. The result of the work of this new Center is five published books, which from various aspects deals with the topic of the Danube Strategy. The latest book presents the theoretical analysis and practical implications of various aspects of the Danube Strat-

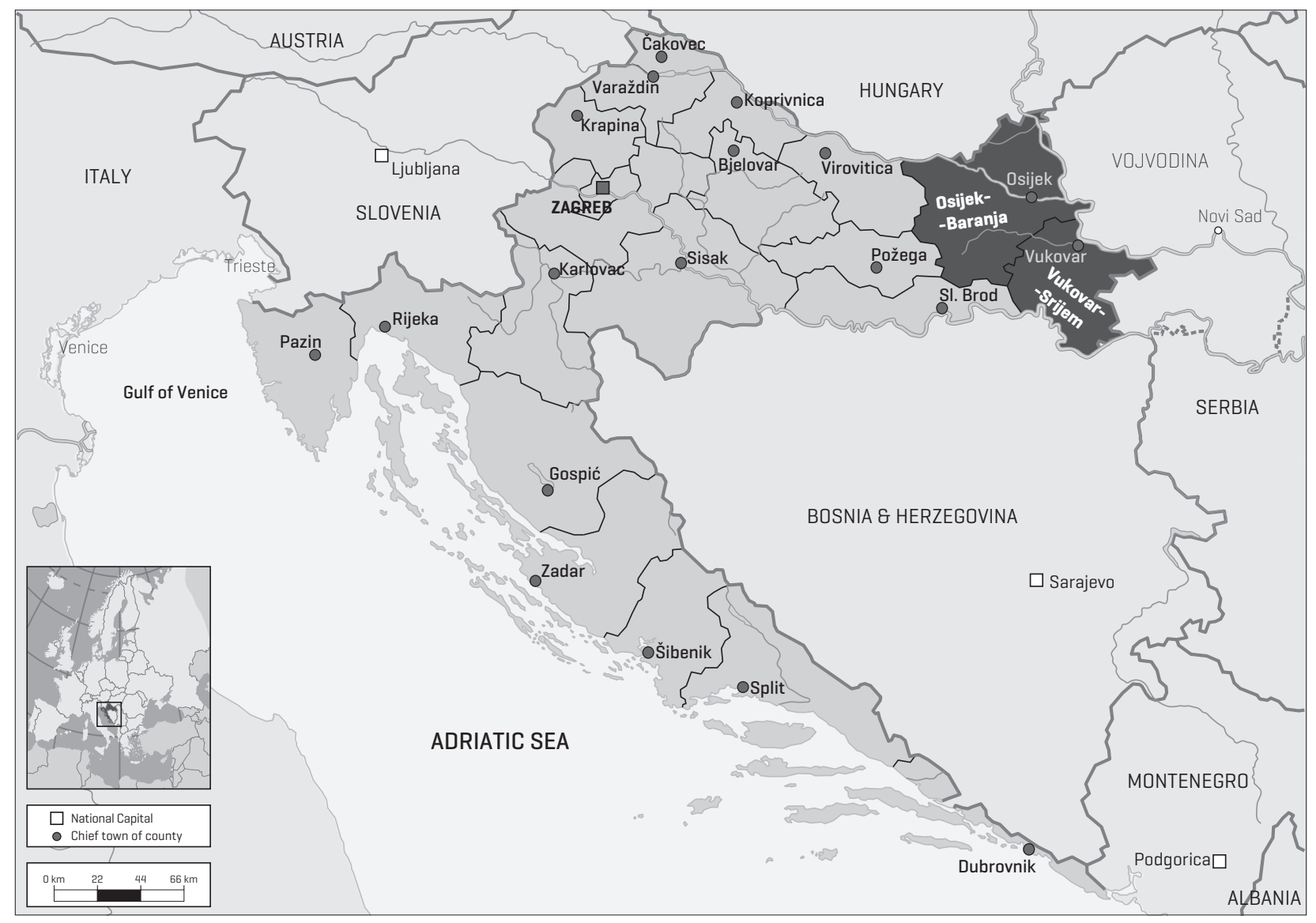

Figure 1. Croatian Danube Region includes two of the easternmost counties, Osijek-Baranja and Vukovar-Srijem 
egy, political, economic, social and cultural challenges related to the Danube Strategy, by authors from different professions, disciplines and nationalities, with the aim of a new, different and interdisciplinary view of the Strategy (Agh, et al., 2010).

Also, certain European researchers dealt with more specific themes or problems of the Danube Strategy such as critical analysis of the Strategy as one of the macro-regional strategies of the European Union, which implies a new political concept for the European Union (Schymik, 2011), followed by possible changes and consequences that the implementation of the Danube Strategy may have on its member states (Busek, Gjoreska, 2010), or they discussed how the Danube Strategy can contribute to territorial cohesion, which is seen as an intensive interrelationship between functional and strategic planning (Giffinger, Suitner, 2010). One of the last papers was that of S. Duhr (Duhr, 2011) which analyzed the experiences of three macro-regional strategies, including the Danube Strategy, and discusses the differences between existing methods and forms of transnational cooperation, as well as whether the strength of each strategy are their strong political commitment, and accentuated involvement of EU institutions, and national ones, in their development and implementation.

Themes of tourism and culture in the framework of the Danube Strategy in the European scientific circles until now have not been dealt as the specific interest of researchers.

In the case of Croatia, the Danube Strategy, as well as some themes, primarily tourism and culture in relation to the Strategy, from an academic point of view are just at the begin to be explored, and this article presents a rare contribution to the research of these themes in Croatian science.

\section{Methods and data}

Research in this paper is based on secondary sources, analysis of approaches and views on the Danube Strategy and its importance, which has so far explored by a small number of mostly foreign researchers since it is a new strategy, and analysis of tourism and culture potentials of the Croatian Danube Region. Since the primary purpose of this paper is the detection of potentials of tourism and culture, as well as specifics of the Croatian Danube Region for sustainable tourism development that will include these potentials, research starts from the assumption that future stronger development of the Croatian Danube Region must be based on attractiveness of the area, and on attractive, interesting and acceptable offers, which will include potentials of tourism and culture. This development must be based on proactive participation of the Croatian Danube Region counties, Osijek-Baranja and Vukovar-Srijem, in the Danube Strategy, especially through its segments of encouraging investments in tourism and culture projects. Development of the Croatian Danube Region has a base on liberal tourist policy and legislation that supports the development, and in interests and preferences of population and community. Also, this development is based on assumptions of sustainability and attractive factors, especially those of tourism and culture.

In this paper will be detected possibilities of applying the Danube Strategy in the Croatian Danube Region through activation of a stronger involvement of tourism and culture potentials as key for sustainable development of this, in terms of tourism, still insufficiently developed part of Croatia. In connection with this hypothesis is proposed which states that the Croatian Danube Region has tourist and cultural attractions that can develop a specific, interesting, friendly, competitive and sustainable tourist product. Proving suggested hypothesis was conducted on following methods:

1. collection and analysis of existing relevant literature and documentation, and analysis of current circumstances relating to tourism and culture in counties of the Croatian Danube Region,

2. collection and analysis the data, information and research of relevant institutions regarding tourism, culture and the Danube Strategy (Ministry of Culture of the Republic of Croatia, Ministry of Tourism of the Republic of Croatia, Croatian National Tourist Board, Ministry of Foreign Affairs and European Integration of the Republic of Croatia),

3. active participation in lectures, seminars and workshops of the Austrian civil society organization, the Danube Civil Society Forum (DCSF), which has a role in promoting active participation of civil society and its networking within the Danube Strategy, and

4. discussions with government representatives at regional and local level in Osijek-Baranja and Vukovar-Srijem County and stakeholders involved in tourism and culture.

Research results in this paper relate to detection of importance of the Danube Strategy and its larger practical use in the Croatian Danube Region, then to detection of tourism and culture potentials of the Croatian Danube Region, as well as an analysis of to date implemented cross-border and transnational projects in terms of better quality and stronger development of tourism in the Croatian Danube Region. In this regard are detected potentials of tourism and culture, which dictates intensity and direction of tourism development in the Croatian Danube Region. Good 
prospects for quality tourism development in the Croatian Danube Region are based on attractiveness of the area, interests and preferences of population and society in general for possibilities to use cross-border and transnational projects, among others, throughDanube Strategy, which all enables realization of sustainable development of this area.

\section{Discussion and results}

\section{The Danube Strategy}

The Danube Strategy consists of the European Commission Communication on the Danube Strategy and Action Plan which was adopted in the course of the European Commission's meeting on December 8, 2010. ${ }^{1}$

The Strategy presents a framework for continued cooperation with the countries of the region, strengthens the identity of the Danube and focused use of funds of the European Union. This is a macro-regional strategy whose main objective is to create a new framework for directed coordination of all interested parties, the EU member states, European regions, the EU institutions, relevant regional organizations, financial institutions and the non government sector, therefore, organization of civil society, in order to achieve a balanced development of the countries of the Danube basin, the region through which the Danube River and all its tributaries flow.

The Strategy includes a variety of EU policies (regional, transport, energy, environmental, safety, and others) and combines them into one functional unit, while maintaining focus on the most significant problems that are common across the Danube macro-region. This so called integrated approach is the foundation of the Strategy, while the " 3 NO" principle - no new institutions, no new sources of funding and no new legislation, is its main principle. This means that the Strategy must be developed and implemented without increasing the financial costs and without any new sources of funding, but exclusively through the existing structures and institutions, and without the adoption of new legal frameworks and instruments. The Strategy is based on four main pillars: ${ }^{2}$

1. connecting the Danube Region,

2. environmental protection in the Danube Region,

Europa. EUR-Lex Home. Commission Communication - EU Strategy for the Danube Region. URL: http://eur-lex.europa. eu/LexUriServ/LexUriServ.do?uri=CELEX:52010DCo715:EN: NOT. 12/12/2011.

2 Detailed: European Commission. Regional Policy - Inforegio. EU Strategy for the Danube Region. Priority Areas. URL: http://ec.europa.eu/regional_policy/cooperate/danube/priority_en.cfm. 12/12/2011.
3. encouraging prosperity in the Danube Region, and

4. strengthening the Danube Region.

Within the framework of four established goals, or pillars of cooperation within the Strategy, within the first pillar - connecting the Danube Region, tourism, as well as culture and its heritage component, are some of the many other areas necessary for the realization of that goal. These four pillars are divided into 11 priority areas, with 253 activities and measures that are specified in the Action Plan. ${ }^{3}$

These 11 priority areas are key areas of the Strategy, their progress is possible through integrative approach, by connecting with other areas, and they are operationalized through projects and activities. Activities are issues that require involvement of countries and stakeholders in order to fulfill the objectives of the priority areas; they do not require additional funding because this is a new, different approach, with better coordination and support. The Action Plan is extremely crucial for the Danube Strategy because it ensures that the activities and projects are realistic, technically and financially sustainable, coherent and supportable. Therefore, tourism and culture, which are closely related in the Strategy, among other things are aimed at strengthening contacts between people and they have a proactive role in its realization.

\section{Croatia and the Danube Strategy}

The Government of the Republic of Croatia accepted the information about the participation of Croatia in the preparation of the Danube Strategy on December 9, 2010. ${ }^{4}$ Croatian participation in this strategic European project opens new opportunities for socio-economic development of the Croatian Danube Region and Pannonian Croatia through the implementation of cross-border and transnational projects with other countries of the region. This is also an opportunity to further strengthen national, regional and local institutional capacities, as well as the application of experience and knowledge gained in the Croatian accession negotiations.

In order to establish effective communication links with the European Commission, and in order to involve a wider circle of Croatian stakeholders in the process of developing the Danube Strategy, the Ministry of Foreign Affairs and European Integration of the

\footnotetext{
3 The integral document of the Action Plan is available at: URL: http://ec.europa.eu/regional_policy/sources/docoffic/official/ communic/danube/action_plan_danube.pdf. 20/12/2011.

4 Government of the Republic of Croatia. Sessions and decisions of the Government of the Republic of Croatia. 96th Session of the Government of the Republic of Croatia. URL: http://www. vlada.hr/naslovnica/sjednice_i_odluke_vlade_rh/2010/96_ sjednica_vlade_republike_hrvatske.12/12/2011.
} 
Republic of Croatia launched interagency cooperation of state administration and regional and local governments. The main goal was to determine the current status and potentials for cross-border and transnational cooperation of the Croatian Danube Region in the context of the Danube Strategy. In this regard, the involvement and coordination of cooperation between all levels of government, especially Croatian counties on the Danube, Osijek-Baranja and Vukovar-Srijem, as well as all the portfolios included in the Strategy, has been identified as crucial.

In the elaboration of Croatian contribution to the Danube Strategy, the principle alignment of national priorities contained in the relevant sectoral strategies, and national strategic referent framework with regional operational program development was applied. Among main development priorities of the Croatian Danube Region is an increase of economic competitiveness through the development of entrepreneurship, modernization of agriculture and development of special forms of tourism. Among the special forms of tourism, in the last ten years, in Croatia is particularly well developed cultural tourism, which has its foundation in the cultural and, especially, heritage resources, which gives culture, in a broader sense, special importance to the framework of implementation of activities and measures of the Strategy. Croatia already has several years of quality cooperation within certain priority areas of the Danube Strategy, including those relating to culture and heritage, particularly through the implementation of numerous projects in which culture and tourism are associated, and appropriate evaluated.

\section{Tourist and cultural potentials of the Croatian Danube Region}

Tourism in the Danube Region is becoming increasingly popular and important in all countries through which Danube River flows. One of the reasons for the increasing importance of tourism in the Danube Region is a general diversification of tourist offer which includes, among other forms of tourism, river cruise tourism as one of the most important form of tourism activities throughout the region. Also, a key reason for increasing importance of tourism in the Danube Region was better, greater security in the region and simplifying border procedures. These circumstances support the development of special forms of tourism in all countries of the Danube Region because they allow a significant increase in tourist activity of tourists who come to any of the Danube countries. Current increase in tourist activities in the Croatian Danube Region is undoubtedly a result of these processes and is expected to provide excellent prospects for further tourism growth and development, particularly after formal Croatian accession to the European Union.
Croatia is one of the ten countries which have been marked by the River Danube. The flow of the Danube River in Croatia is the shortest in comparison to other countries, and along the banks of the river there are no large cities. The largest Croatian city on the River Danube is Vukovar, with approximately 30.000 inhabitants. The length of the Danube River in Croatia is only $188 \mathrm{~km}$, and almost entirely it is the border area between Croatia and Serbia. However, the Croatian Danube Region is a very important area and space for Croatia, which includes two counties, Osijek-Baranja and Vukovar-Srijem. This is one of the most fertile parts of the Croatia which due to the numerous natural and, especially, cultural attractions has become one of the most significant continental regions of Croatia. (Fig. 2)

The Croatian tourism development strategy focuses on the coastal area, although it recognizes the potentials of continental Croatia, such as cultural tourism, ecotourism, health tourism, conference tourism, and others, but it singles out the potential of the Croatian Danube Region in rural tourism, hunting, fishing and various other activities in the countryside. ${ }^{5}$

However, there are no issued measures that could be implemented in terms of intensive development of tourism in the Croatian Danube Region. There are several strategic documents related to tourism development in the Croatian Danube Region, these are spatial plans, regional operational plans, master plans for tourism and local development plans. ${ }^{6}$

Regional operational plans of Osijek-Baranja and Vukovar-Srijem County give a special emphasis on the development of tourism and various tourism products. However, it should be take into consideration that regional operational plans have no operational force and do not offer sufficiently effective mechanisms to implement projects themselves. On the other side, spatial plans that identify specific areas of development do not offer a strategic approach, and within them tourism does not have an important role. Although both counties have master plans for tourism, they are still either not implemented or not accepted

\footnotetext{
5 For further information see: Strategy for development of Croatian tourism to 2010. 2003. Ministry of Tourism of the Republic of Croatia, Zagreb. URL: http://www.mint.hr/UserDocsImages/Strategija\%2ohrvatskog\%2oturizma\%20-\%2ofinalna\%20 verzija.pdf. 25/12/2011. At the time of writing this article, the draft of the „Master plan and development strategy of tourism of the Republic of Croatia" was being counducted, and it is lead by the Institute for tourism in Zagreb.

6 List of existing strategic documents related to the development of tourism in the Croatian Danube Region see in: Transnational Strategy for the Sustainable Territorial Development of the Danube Area with a Focus on Tourism DATOURWAY. National Study - Croatia. 2010. Zagreb, 55. URL: http://www.datourway.eu/documents/88-701-8910-dat_cro_wp3_analysis_en.pdf. 19/12/2011.
} 
in the preliminary versions. Some of the local plans include very important activities related to tourism development such as the protection and enhancement of cultural and natural heritage, and education and training of local service providers.

\section{Tourism of the Croatian Danube Region}

Regarding tourism in the Croatian Danube Region, it is one of the least tourism developed areas of Croatia. According to statistics, Osijek-Baranja County achieved total of 71.749 arrivals and 159.261 overnight stays in year 2010. Most arrivals and overnight stays were in Osijek, which has the largest number of regular visitors, 2228. In the Vukovar-Srijem County, in 2010, there were a total of 36.582 tourist arrivals and 68.383 overnight stays. The largest number of tourist arrivals and overnight stays was registered in Vinkovci, which achieved the largest number of visitors, 601, and then in Vukovar. ${ }^{7}$

Comparing the data from 2010 with that from 2009, Osijek-Baranja County recorded a lower number of arrivals and overnight stays in 2010, because in 2009 the total was 78.382 arrivals and 187.422 overnight stays. There were, therefore, about $7.7 \%$ less tourist arrivals and $15 \%$ less overnight stays in 2010 , compared to 2009. In the case of the Vukovar-Srijem County, the data shows a different situation. In 2009 there were fewer arrivals (33.828) compared to 2010 (36.582), but 2009 saw more overnight stays (78.033) than 2010 (68.383). In the case of Vukovar-Srijem County, the number of arrivals in 2010, compared to 2009, increased $5.9 \%$, but the number of overnight stays decreased $12.8 \%{ }^{8}$

According to data available for the first nine months of 2011, ${ }^{9}$ Osijek-Baranja County recorded an increase in the number of tourist arrivals from a total of 56.853 compared to the same period in 2010, when there were 52.820 arrivals. A rising trend is evident in the number of overnight stays, this year until the end of September there were 130.961, as opposed to 120.084 in the same period in 2010. The Vukovar-Srijem County has also registered an increase in the number of tourist arrivals in the first nine months of 2011 with 27.318 arrivals, while in 2010, the number of arrivals was 25.594 . However, the number of overnight stays is less than the number of overnight stays recorded from January to September 2010, when there were 49.903 overnight stays, while in 2011, there were 47.297 .

7 Further information in: Tourism in 2010. Statistics reports. 2011. Croatian Bureau of Statistics, Zagreb, 59.

8 Ibidem., 62.

9 Republic of Croatia. Ministry of Tourism. Statistics. 2011. Tourist traffic in September and the first nine months. URL: http:// www.mint.hr/UserDocsImages/111104-1-9-stat.pdf. 19/12/2011.
According to the above statistics it can be concluded that tourism in two Croatian Danube counties is registering growth, especially in the number of tourist arrivals, while the number of overnight stays varies and the Vukovar-Srijem County is registering a decline. This could be attributed to global recession trends, i.e. the current general crisis, as well as an insufficient number of permanent beds. The VukovarSrijem County has a small number of permanent visitors, just 979 in 2010, as opposed to the 2228 permanent visitors in the Osijek-Baranja County. ${ }^{10}$ This data indicate an increase in the importance of tourism in the Croatian Danube Region.

Tourism takes a very important place in the economic development of the Osijek-Baranja County as one of the most powerful promoters of growth. In fact, tourism has a exceptionally strong impact on the area in which it develops, creating additional, new markets for a wide range of economic activities such as culture, trade, agriculture, health, transport, and others. The current attractions are the basis for tourism development in the Osijek-Baranja County, as well as for the numerous selective forms of tourism: cultural, excursions, educational, environmental, hunting, fishing, health, rural, nautical, congress, transit, pilgrimage, and others. These attractions are:

- richness of waters (rivers, lakes, thermal springs),

- forest and woodland areas with mostly preserved ecosystems of flora and fauna,

- preserved fund of wildlife,

- protected natural areas,

- significant rural areas, and

- rich cultural heritage, material and nonmaterial.

Special value has the Nature Park "Kopački rit" which is located in the southeastern part of Baran$\mathrm{ja}$, on the natural floodplain of European importance, and because of its natural importance has been added to the list of internationally significant wetlands. However, "Kopački rit" is not sufficiently used for tourism purposes as evidenced by a very modest number of visitors, ${ }^{11}$ but intensely considers its systematic inclusion in the tourist offer of the region (Ćućić, et al., 2007, 453-479).

Although slow, visible progress can be seen in the development of rural tourism on family farms, also

10 Tourism in 2010. Statistics reports. 2011. Croatian Bureau of Statistics, Zagreb, 59.

11 Information on the state and tourism development opportunities in the Osijek-Baranja County and the activities of County Tourist Board. 2011. Osijek. URL: http://www.obz.hr/ $\mathrm{hr} / \mathrm{pdf} /$ gospodarstvo/2010/Informacija\%200\%20stanju\%20 i\%2orazvojnim\%2omogu\%C4\%87nostima\%2oturizma\%2o na\%2opodru\%C4\%8Dju\%2oOsje\%C4\%8Dko-baranjske\%2O \%C5\%BEupanije\%2oi\%2oradu\%2oTuristi\%C4\%8Dke\%2ozajednice\%20\%C5\%BDupanije.pdf. 25/12/2011. 


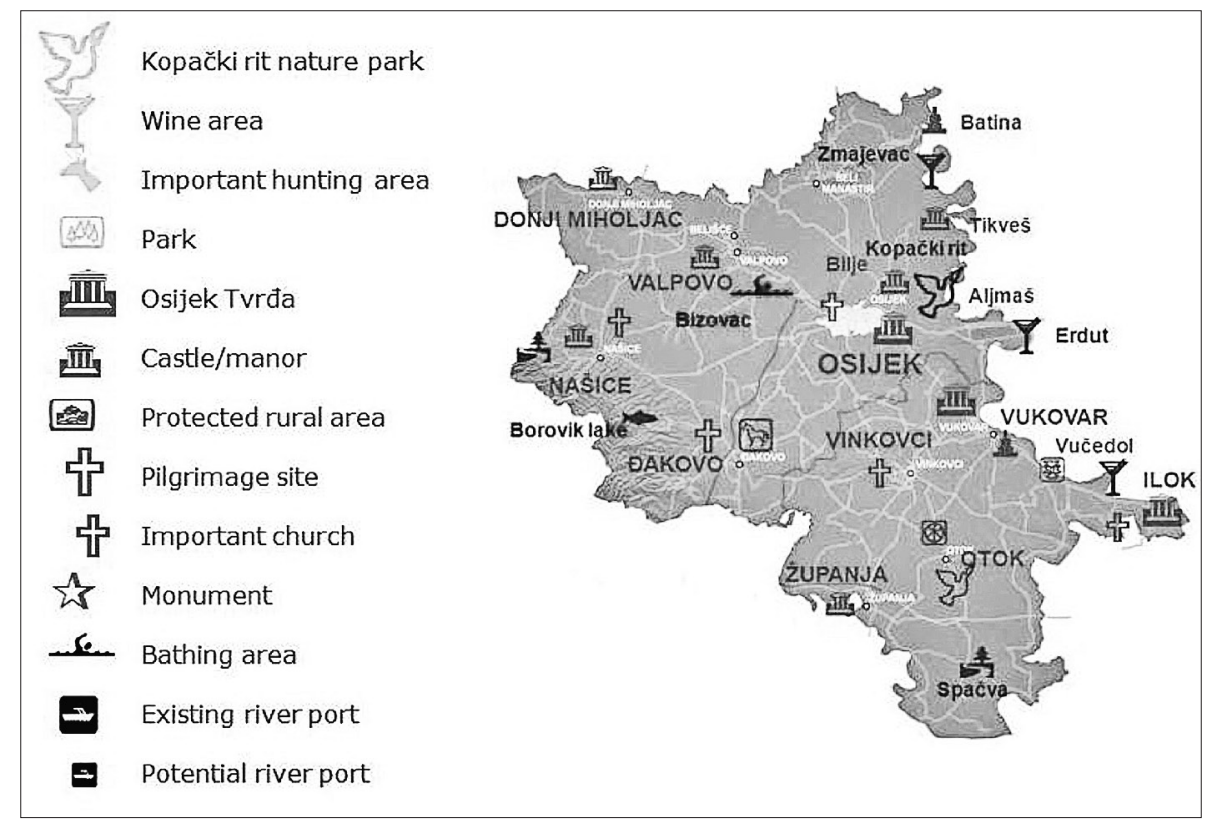

Figure 2. Main tourist attractions in Croatian Danube Area

in the tourist offer of the Nature Park "Kopački rit", in hunting tourism, and in the inclusion of the County, respectively its cities as destinations of several days cruising on the Danube River. According to policy documents, numerous and varied programs and activities have been proposed in order to encourage tourism in the County, and of importance are programs for comprehensive integration of cultural heritage for tourism purposes, the development of wine routes, hunting and, especially, rural tourism. Implementing subjects of these programs and activities are regional and local governments, the private sector and local residents which ensures their implementation and the achievement of appropriate effects/results. ${ }^{12}$

A growing number of rural farms are engaged in rural tourism (Mišćin, Mađer, 2008). This is particularly relevant in the context of EU trends where the emphasis is more on rural development instead of agricultural development. Thus, creating the preconditions for sustainable development of rural areas by strengthening and diversifying the economic base in the complementary activities of agriculture, among which rural tourism is one of the options for development. A significant number of rural family farms has been producing wines and represent an significant segment of development of rural areas and rural tourism through wine roads. ${ }^{13}$

12 For more see: County Development Strategy of Osijek-Baranja County 2011-2013. 2011. Osijek, 67-69.

13 Lists and descriptions of wine roads in the Osijek-Baranja County are available at: Wine-tourist roads of the OsijekBaranja County. 2011. Osijek. URL: http://www.tzosbarzup.hr/ UserFiles/File/pdf/broshura_gotovo_2.pdf. 19/12/2011.
In particular, it is necessary to emphasize the importance of Local Action Groups, LAG-s (two registered as NGOs in the Osijek-Baranja County: LAG Karašica and LAG Baranja), and the application of the LEADER approach in the development of rural areas of the County. Local Action Groups gather all stakeholders in their area and organize them into a publicprivate partnership for the joint consideration of local development, primarily through preparation of local development strategies, than through projects that will be financed from funds of the IPARD, as well as from EU funds intended for rural development.

The Vukovar-Srijem County suffered extremely severe damage in the war (from 1991 to 1995), which significantly slowed down its economic development. There was a distinct stagnation in the tourism sector in relation to the period before the war. However, tourism has a very important role in strategic planning for economic development of the County. Based on resources such as natural beauty, exceptionally valuable archaeological sites, cultural heritage, ethnographic heritage, offer of high quality and indigenous food and developed viticulture. What is especially important is to have an appropriate international traffic route, which would make all sites and destinations easily accessible.

Analysis of tourist and cultural potentials of the County shows that natural resources have high value (forests of the Spačva Basin, a number of protected areas, protected plant and animal species), and then cultural (archaeological sites Vučedol and Sopot, the old urban center of Ilok, and others), as well as some special forms of tourism such as wine tourism (Ilok, Vukovar). However, other forms of tourism are important in the development of tourism in Vukovar-Srijem County: 
- fishing tourism (more than 50 fishing-sporting associations),

- hunting tourism (large forest areas with a varied and numerous animal population),

- manifestations (34 in the entire county, the most famous is "Vinkovačke jeseni"),

- cycling tourism (two international routes, Danube and Sava, while the overall length of the cycling trail is $184 \mathrm{~km}$ ),

- memorial tourism (Memorial Cemetery in Vukovar, Ovčara - Memorial Center, War Museum of the Vukovar Hospital),

- cultural tourism (Castle Eltz in Vukovar, archaeological parks Vučedol and Sopot, traditional theme paths "Cesta zlatne niti", "Put voćne kapi”, "Iločka vinska cesta”),

- nautical tourism (sole continental county with two ports/docks, Vukovar and Ilok, for international cruisers, which bring foreign guests in continental counties),

- recreational tourism (numerous tennis and soccer courts, a number of walkways along Danube, Sava and Bosut), and

- equestrian tourism (numerous horse trails between towns and municipalities, recreation and rehabilitation programs of horseback riding, international competitions in equestrian sports). ${ }^{14}$

\section{The cultural heritage}

\section{of the Croatian Danube Region}

The cultural heritage of the Croatian Danube Region is very rich and diverse, although there are no sites listed on the UNESCO World Heritage List, as is the case in the Croatian coastal area, where there are six protected sites. ${ }^{15}$ However, in the Croatian Danube Region there is example of nonmaterial heritage, from a total of nine UNESCO protected in Croatia, which is the Spring Procession of Ljelje/Kraljice (Queens) in Gorjani, a village

${ }^{14}$ For more information: Transnational Strategy for the Sustainable Territorial Development of the Danube Area with a Focus on Tourism DATOURWAY. National Study - Croatia. 2010. Zagreb, 133-134. URL: http://www.datourway.eu/documents/88701-8910-dat_cro_wp3_analysis_en.pdf. 19/12/2011, as well as: Development strategy of Vukovar-Srijem County 2011 - 2013. 2011. Institute for International Relations (IMO), Zagreb; Development Agency of Vukovar-Srijem County HRAST d.o.o., Vukovar. URL: http://www.vukovarsko-srijemska-zupanija. com/upload/paragrafi_upload/2011-7-6_2836819_ZRSVSZ-Final.pdf. 19/12/2011.

15 These are: Early-Christian Euphrasian Basilica in Poreč, Historic center of Trogir, Palace of Diocletian and medieval Split, Old City of Dubrovnik, Cathedral of St. James in Šibenik and Starigrad field on Hvar, and on the tentative list there are 16 more cultural and natural resources. For more details: Croatia UNESCO World Heritage Center. URL:http://whc.unesco.org/ en/statesparties/hr. 13/12/2011. near Đakovo. ${ }^{16}$ Also, there are two facilities that are located in the Croatian Danube Region, and are included in the UNESCO Tentative list: the Croatian part of the borders of the Roman Empire - the Danube limes along the Danube River from Batina to Ilok, ${ }^{17}$ and the historical-town planned ensemble Tvrđa in Osijek from the 18 th century, ${ }^{18}$ which can undoubtedly be considered as the most attractive cultural monument of the wider Danube Region, not just on its Croatian part. Numerous heritage sites include archaeological remains from the Roman and pre-Roman period, ${ }^{19}$ churches ${ }^{20}$ castles and patrician houses, ${ }^{21}$ ethnological heritage, ${ }^{22}$ old wine cellars ${ }^{23}$ and monuments from recent history. ${ }^{24}$ Also, in the Croatian Danube Region is possible to visit museums, galleries and art colonies, as well as international seasonal festivals of music and film. This rich and diverse cultural heritage presents not only a very valuable and important cultural component of the Croatian Danube Region, but also an important tourism resource that could be used for further development, strengthening and growth of tourism of the area and its sustainable development.

16 UNESCO. Culture. Intangible Heritage. Spring Procession of Ljelje/Kraljice (Queens) from Gorjani. URL: http://www.unesco.org/culture/ich/index.php?lg=en\&pg $=00011 \& R L=00235$. 26/12/2011.

17 UNESCO. Culture. World Heritage Centre. The List. Global Strategy. Tentative lists. Frontiers of the Roman Empire Croatian Limes. URL: http://whc.unesco.org/en/tentativelists/2014/. $27 / 12 / 2011$

18 UNESCO. Culture. World Heritage Centre. The List. Global Strategy. Tentative lists. Historical-Town Planning Ensemble Tvrda (Fort) in Osijek. URL: http://whc.unesco.org/en/tentativelists/161/. 27/12/2011.

19 The most significant archaeological monument is the archaeological site Vučedol from the prehistoric Bronze Age, which is regarded as one of the most important in Europe from that period. For more information: Republic of Croatia. Ministry of Culture. Projects of the Ministry. Project „Vukovar-VučedolIlok". URL: http://www.min-kulture.hr/default.aspx?ID=10o. 13/12/2011. The site Vučedol, seriously damaged during the war in 1991, has still not been restored to a state in which it could be presentable to tourists.

20 For example, the Đakovo Cathedral from the 19th century, built in the historicist style (Damjanović, 2009), the Osijek Cathedral, then the Church of St. Elias on Meraji in Vinkovci, St. Anthony of Padua in Našice, John of Capistrano in Ilok, a small church of St. Peter and Paul in Topolje, in Baranja, and many others.

21 Especially the Eltz Castle in Vukovar, as well as patrician houses in Donji Miholjac, Našice, Valpovo, Bilje, Tikveš near Kopački rit, and others. More in: Šćitaroci, 2001.

22 Rich ethnological heritage can be seen in numerous traditional celebrations throughout the region, the most important and famous are "Vinkovačke jeseni" and "Đakovački vezovi".

${ }^{23}$ There are numerous wine cellars in Baranja, Erdut, and elsewhere.

24 Recent history is most present in the Vukovar Museum on Ovčara and at the Memorial Cemetery for victims of the War for Independance. 


\section{Projects of culture and tourism in the Croatian Danube Region}

Recognized cultural heritage of the Croatian Danube Region are already the starting point in several international projects based on culture, as well as in those that connect culture and tourism. The major projects that are based on the cultural heritage of the Croatian Danube Region are cited and briefly described as follows.

Projects within the pre-accession INTERREG IIIA program are "Cultural-tourist cooperation between Osijek-Baranja County, Croatia and Baranja County, Hungary and cities of Osijek and Pečuh" and "Digital history". The aim of the project "Cultural-tourist cooperation between Osijek-Baranja County, Croatia and Baranja County, Hungary and cities of Osijek and Pečuh" was to strengthen the candidacy of Osijek's old town Tvrđa in order to include it on the list of protected UNESCO World Heritage Sites. From the Croatian side, the project was implemented in the Osijek-Baranja County (City of Osijek and municipality Draž). The aim of the project "Digital history" is to promote religious tourism destinations in the crossborder region of Croatia-Hungary in a contemporary way, using modern technology and digital media (CD-s, DVD-s, etc.). From the Croatian side, the project was implemented in the Osijek-Baranja County.

The "Ethno-brand" project was implemented within the pre-accession program INTERREG Adriatico. The aim of the project was to develop tourism potentials of Slavonia and Baranja through strengthening of social entrepreneurship in production of indigenous crafts. From Croatian side, the project was implemented in the Osijek-Baranja County.

One of the most important tourism development project with a strong cultural component implemented under both national (the Government of the Republic of Croatia, the Vukovar-Srijem County, cities and municipalities, economic sector, and other) and international (PHARE 2006, Interreg IIIA, Austrian Government, ADA-Austrian Development Agency, and other) financial support in the Vukovar-Srijem County is "Research, restoration and revitalization of cultural heritage of Ilok-Vukovar-Vučedol". The aim of the project is to examine, restore and present cultural heritage, raise awareness of population, strengthen development of tourism, employment and regional development. The total value of the project is 35.6 million euro, and it is financed by the Croatian Government and the Council of Europe Development Bank.

In the Croatian Danube Region already in the implementation are various projects of culture and tourism, which develops as a transnational projects and confirm a proactive role of Croatia in the Croatian
Danube Region. These projects are in various stages of development and implementation, with specific and recognizable impacts that contribute to the sustainable development of the area. At the same time, they confirm so called "Danube identity" of Croatia. These projects are mainly conducted by the administrative bodies of the Vukovar-Srijem and Osijek-Baranja County, as well as by their regional development agencies, and in these projects are involved some ministries such as the Ministry of Culture and the Ministry of Tourism of the Republic of Croatia. Among the projects related to culture, there are, for example: "Danube limes in Croatia", digital cultural map "Danube - way of culture", already mentioned "VukovarVučedol-Ilok", then the archaeological park "Sopot", and others, while among the tourist projects stand out "Datourway" and "Danube bicycle route EuroVelo 6".

In order to approach European standards in the research of the limes in Croatia, within the project "Danube limes in Croatia", ${ }^{25}$ in the second half of 2008, the Archeological Museum in Osijek opened an office for the limes. It acts as an organization that collects existing documentation on the limes, publications, archive materials and maps of limes sites. Some air and geodetic recordings have already been made. When, based on them, will be a clear view of the situation, the next step will be creating an overview of the field and selecting sites that will be included on the list of protected areas. The position of the limes in relation to cultural groups from other time periods and the Nature Park "Kopački rit" will be determined. In 2005, thanks to the Ministry of Culture of the Republic of Croatia (MKRH), the Croatian part of the limes has been reported on the UNESCO Tentative list of world heritage. It is especially important to mention cooperation between the MKRH with County, city authorities and institutions in the Danube Region. So far, our knowledge of the Croatian part of the limes derives from the reconnaissance, random findings, safety research and written sources, and its research are an extensive and lengthy process. By applying the geophysical method of magnetometer, any part of the limes can be included on the UNESCO World Heritage List as soon as it is documented and published in this way and that is why archaeological researches are not required. Meanwhile, by properly placing information and use of oral tradition, we should work on building and maintaining the new (old) identity, knowledge about the monument and increasing cultural awareness of the local population.

Within the Working Body "Culture and Science" of the Working Community of Danubian Regions, in co-

${ }^{25}$ Danube limes in Croatia. URL: http://www.dunavskilimesamo.com.hr/index.html. 13/12/2011. 
operation with MKRH, a cultural-tourist map "Danube - way of culture" is being made. ${ }^{26}$ The map includes sites on the Danube Region in the zone of up to $50 \mathrm{~km}$ distance from the Danube River. The area covered by the Republic of Croatia includes 41 sites with 187 cultural goods, illustrated with 40 photographs.

Project "Datourway" is an example of transnational cooperation related to development of tourism along the Danube River in its central and southeastern part. ${ }^{27}$ This project pays special attention to the protection and preservation of natural and cultural resources associated with this large European navigational route. The concept of tourism in this project is understood in a wider sense. It is seen as a complex activity that is oriented toward recreation, rest and leisure, cultural enrichment, enjoying the natural beauty and physical movement, regardless of the duration of stay. In addition, the project aims to strengthen and promote transnational cooperation in tourism related to various tourist potentials of the river, its shores, the natural beauty of the river coastal areas, and architectural heritage villages, towns and villages along the Danube River. Way of functioning of the "Datourway" is achieved by transnational agreements on joint tourism strategy and integration policies, and pilot projects at national, regional, local and European plans and policies. Considering that in Croatia there is a need to establish a sort of balance between coastal and continental (inland) areas for the purpose of tourism, and project "Datourway" should promote areas along the Danube River and to raise recognition of their potentials.

"The Danube bicycle route" or "Route Danube" is part of the international cycling route "EuroVelo 6", the European Cycling Network "European Cycle Route Network", that stretches from the Atlantic Ocean to the Black Sea. ${ }^{28}$ It is also part of the international Danube cycling route "Cycling Danube", which is co-financed by the IPA II program, its component for cross-border cooperation. The goal of the project "Route Danube" is to strengthen recreational cycling tourism in the cross-border region as a form of selective tourism that recorded strong growth. Project partners in Croatia are the Tourist Board of the $\mathrm{Vu}$ kovar-Srijem County and Osijek-Baranja County, in Serbia a leading partner is the Municipality Bačka Palanka. In Croatia, throughout 2005, there has been

26 Republic of Croatia. Ministry of Culture. Cultural heritage. Danube - way of culture. URL: http://www.min-kulture.hr/default.aspx?id=1717. 13/12/2011.

27 Transnational Strategy for the Sustainable Territorial Development of the Danube Area with a Focus on Tourism DATOURWAY. National Study - Croatia. 2010. Zagreb. URL: http://www. datourway.eu/documents/88-701-8910-dat_cro_wp3_analysis_ en.pdf. 19/12/2011.

28 EuroVelo 6. URL: http://www.eurovelo6.org/. 13/12/2011. tracing of the "Route Danube" through the VukovarSrijem and Osijek-Baranja County with the length of $138 \mathrm{~km}$, and setting the necessary signalization. Especially interesting is the Ilok part of the route $(17 \mathrm{~km})$, passing through Mohovo, Šarengrad and Ilok, due to the height difference and diverse landscape.

The Osijek-Baranja County, within the Danube Strategy, concerning the field of tourism, is predicted to have a more prominent development of special forms of tourism, and development of new tourism products such as: bicycle trails, wine routes, the reconstruction of castles, honey trails, old crafts and trades, revitalization of Osijek Tvrđa, and others. ${ }^{29}$

The Vukovar-Srijem County is very active in projects on the regional level. ${ }^{30}$ Since 2004, the County is a full member of the Working Community of Danube Regions, established in 1990, in Wachau, Austria. The goal of the Working Community of Danube Regions is to use cross border cooperation of regions in the Danube Region in order to encourage economic development, transport, spatial planning, tourism, culture, science and environmental protection. By encouraging the cooperation of its members, the goal is to contribute to the development of the Danube Region in the interests of the local population and peaceful cooperation in Europe. To date, the membership of the Working Community of the Danube Regions has joined 38 regions covering $650.000 \mathrm{~km}^{2}$ that have around 80 million inhabitants. The most important projects of the Working Community of Danube Regions for Croatia, initiated by the working groups "Economy and Tourism" and "Culture and Science", are the concepts of cycling routes along the Danube River and the digital cultural map "Danube - way of culture. ${ }^{31}$

\section{Opportunities for tourism development in the Croatian Danube Region}

The resource value and attractiveness of the Croatian Danube Region, i.e. the Osijek-Baranja and Vukovar-Srijem County, serve as a fundamental starting point for the development of tourism. From this also

29 „Osijek-Baranja County in the context of the Danube Strategy“. Presentation held on local event „Open Days 2010" in Osijek, October 10, 2010. URL: http://www.slavonija.hr/images/ Dokumenti2010/hr/Osje\%C4\%8Dko\%20-\%2obaranjska\%20 \% $5 \%$ BEupanija\%2ou\%2okontekstu\%2oDunavske\%2ostrategije.ppt. 13/12/2011.

30 "Vukovar-Srijem County in the context of the Danube Strategy". Presentation held on local event "Open Days 2010" in Osijek, October 10, 2010. URL: http://www.slavonija.hr/images/Dokumenti2010/hr/Vukovarsko\%20-\%2osrijemska\%20 \% $5 \%$ BEupanija\%20u\%20\%2okontektsu\%2oDunavske\%20 strategije.ppt. 13/12/2011.

31 Official web site of Vukovar-Srijem County. Working Community of Danube Regions. URL: http://www.vukovarsko-srijemska-zupanija.com/vsz.php?stranica=114. 13/12/2011. 
derive the basic objectives of tourism development of both counties and that is the achievement of economic well-being of their populations while ensuring the necessary level of protection of nature and the environment, and rational use of natural resources. Approach to the integral use of spatial-environmental, traffic, cultural and human resources and "sustainable development" is a model for achieving this goal. Implementation of programs which aimed to revive economic activity and preservation of cultural heritage were realized appropriate results that are reflected in:

- increasing the number of providers of tourist services in both counties,

- renovation of traditional buildings, old skills and crafts, and

- opening of new sales channels of local products and services.

By investing in heritage, preservation has saved many buildings of architectural heritage from further deterioration through a new tourism purpose. The program of tourism development in rural areas and crediting rural households authorized for the provision of catering services have contributed to the increase of registered rural households. Counties of the Croatian Danube Region understand the need to develop continental tourism and in their regional operational programs emphasized goals and measures that are needed to build a tourist offer in the counties as a distinctive tourist destination with an emphasis on ambient, natural, traditional and cultural values. Measures that have been implemented and should continue to implement are:

- use of tourist offer based on natural resources (Nature Park "Kopački rit", geothermal waters, ecotourism),

- renovation of old crafts in the function of tourist offer,

- restoration and protection of cultural heritage,

- integration of various tourist offers with the goal of encouraging and developing all forms of tourism, and

- promotion of continental tourism and interregional cooperation in creating tourist offer.

Considering that both counties have the potentials to develop many types of special forms of tourism and that in last years increased interest in visiting these destinations, it should persist in the preparation of strategies for tourism development of both counties, which would unite all segments of tourist offer in them.

Therefore, the Croatian Danube Region, that is the Osijek-Baranja and Vukovar-Srijem County, have good resource potentials for tourism development.
The Croatian Danube Region is characterized by advantageous geographical position of the three principal rivers, the Danube, Drava and Sava; availability, particularly road connections, and river links between the rivers Danube and Drava; numerous attractive and well-protected natural resources, especially forests and wetlands; attractive areas suitable for development of wine tourism; rich cultural heritage, especially archaeological; rich ethnological heritage; customs, traditional performances/manifestations, gastronomy; hospitality of the population; diversification of tourism products and high quality accommodation facilities. In recent years, attention is focused on developing and implementing educational and training programs for the tourism sector, the establishment of enterprises in the tourism sector, as well as marketing companies for tourist destinations on regional and local levels, all of which, among other things, contribute to forming and strengthening the image of the Croatian Danube Region as an attractive area for holidays/vacation. The excellent conditions for agricultural production must not be forgotten, which represent an additional incentive for development of food industry. In addition, it should be mentioned that a larger number of projects for development of tourist products in the Danube Region, and an increasing number of projects related with development of different forms of tourism in two counties of the Croatian Danube Region is proof of welldeveloped regional cooperation.

However, tourism of two counties also has numerous problems and weaknesses. Primarily, a remarkably small number of tourists overnight stays especially of foreign tourists. Then, there is extremely slow modernization of existing tourism infrastructure, therefore, accommodation and catering facilities, roads, attractions, themed trails and facilities in the function of selective tourism. This is followed by complex registration procedures of new service providers in tourism, as well as selective application of existing laws, regulations and other legislation. Thus, there are complex legal framework for tourism business and long administrative procedures (such as obtaining permits) when starting a business. There is no strategic framework for development of continental tourism, particularly lack of appropriate strategies of development of continental tourism at all levels. There is also a lack of consistent management of destinations and interconnection of smaller thematic routes, lack of services related to tourism such as information, guides, transportation, and others, and lack of systematic promotion of destination and appropriate tourist information center in counties. It should also be noted there is not enough attention to agricultural production, and a stronger, more distinct involvement of agriculture in tourism is 
necessary. Also, there is not enough awareness of the need for continuing education and human resource development in tourism, and lack of regular general and specialized education programs for the workforce in tourism. That is, in general, a lack of entrepreneurial spirit in tourism, accompanied by lack of capital for investment in tourism.

Consequently, opportunities and development needs related to tourism of the Croatian Danube Region should include a range of activities and measures, implementation of which should allow proper use/operation of tourist and cultural potentials, effective and sustainable development of both counties. First of all, it should better exploit opportunities provided by the fact that Croatia soon becomes a member of the European Union. Furthermore, trend for continental tourism continues to grow, giving potentials for hunting, fishing, and in particular, rural tourism, which is abundant in both counties of the Croatian Danube Region, providing additional opportunities for their use and development. Related to this is use of underutilized and, to date, unused tourist resources in both counties, especially monuments of cultural and natural heritage, which needs renovation in order to be placed in function. Attention should be paid to the promotion and branding of specific tourism products, as well as strengthening the image of the Croatian Danube Region as a "green destination". Since the continuing education is very important factor in successful tourism, it is necessary to strengthen awareness of the need for continuous education and human resource development in tourism, to develop educational programs for workforce in tourism.

As above mentioned projects of tourism and culture in the Croatian Danube Region showed, Croatia within the framework of the Danube Strategy can take advantage of the full potentials of its cultural heritage and develop them effectively. These projects also confirm awareness of regional and local communities about the necessity of cross-border cooperation in the fields of culture and tourism, and realization of projects focused towards sustainable development of the whole area. Furthermore, the improvement and development goals of culture and cultural heritage, as well as tourism, in the Danube Strategy are complementary to those of the Republic of Croatia. The Danube Strategy in the fields of tourism, culture and cultural heritage offers many opportunities to better taking advantage of transnational and cross-border cooperation programs, which can unleash entrepreneurial potentials with which it can apply for funds from the European Union. In this regard should continue to insist on the preparation and implementation of numerous projects for development of tourism infra- structure that could be financed both through national funds and the resources/support from the European Union. However, it is necessary to adopt a plan of development of continental tourism at national and regional levels. Special attention should be given to an equal application of existing legislation on all subjects in tourism, and insist on simplification, operationalization of procedures for registering new service providers in the tourism industry. Also, it should continue to insist on improving cooperation between private, public and nongovernment sector and civil society in the field of tourism. Considering the potentials of the Danube as a region should foster policy of appreciation of the benefits of the Danube River as a fact or for integration of cross-border and transnational tourism development, linking tourism markets of the Danube countries and development of joint cultural tourism products.

\section{Conclusion}

The Croatian Danube Region has enough potential for tourism development due to its unique natural resources and rich cultural heritage. These valuable resources are an adequate basis for development of numerous selective forms of tourism in both counties in the Croatian Danube Region, such as rural and ecological tourism, cultural, wine and gastronomical, then active tourism such as cycling, fishing and hunting, horseback riding, and others. However, these cultural and tourist potentials, with a excellent geographical position and an infrastructure in development, are not sufficiently and appropriately used. This is because development of continental tourism in Croatia until recently was neglected, considering that Croatia is a global recognized as one of the most beautiful sea tourist destinations. Recently, at the regional level, development of tourism in the Croatian Danube Region receives a significant place as one of the strategic priorities in development planning documents.

In the tourism sector of the Croatian Danube Region, recent years have been marked by preparation and implementation of a significant number of crossborder and transnational projects, as well as strengthening of entrepreneurial activities. These projects confirm operationalization of the Danube Strategy as a macroregional strategy, because it ensures more intensive cooperation within existing forms of cooperation, as well as thematic consistency of projects that have greater opportunities to obtain funding, and their successful implementation. In this regard, it is of particular importance that Croatia actively participates in implementation and realization of the goals of the Danube Strategy. In this way, the Danube River will be confirmed as one of more important factors of eco- 
nomic, urban, cultural and historical development of Croatia. It presents rich potential for effective European cooperation of national and regional development, in which river with its potentials affects various project segments, including those in the tourism sector. Considering that tourism potentials of the Croatian Danube Region are largely based on natural attractions, tourism can be considered as a better option for regional development, in comparison with other sectors such as industry. In order for these potentials to be effectively developed in the Croatian Danube Region, i.e. in its two counties Osijek-Baranja and Vukovar-Srijem, it is necessary to continue to focus on strategic development, strengthening and growth of tourism, consistent management and promotion of destinations in the context of monitoring trends in tourism demand, organize a network of stakeholders in tourism and aimed to improve transport infrastructure in function of tourism. Croatia can achieve these goals with proactive participation in the Danube Strategy. Investment promotion, among others in projects of tourism and culture, the Strategy contributes to ensuring functional unity of the region by taking advantage of its potentials by appropriate use of EU funds, which may further motivate local authorities on more efficient use of available resources for tourism development and potentials for public-private partnerships for realization of projects in tourism. Finally, the Danube Strategy provides clear identification of projects in the field of tourism and culture, and by coordinating different levels of government and involving other stakeholders, ensures their financial and operational sustainability, effective implementation, which leads to significant economic benefits.

\section{References}

Agh, A., Kaiser, T., Koller, B. (eds.) 2010. Europeization of the Danube Region: The Blue Ribbon Project. „Blue Ribbon Research Centre“ King Sigismund College, Budapest, $260 \mathrm{pp}$.

Busek, E., Gjoreska, A. 2010. The Danube Region: transformation and emergences. Eastern Journal of European Studies 1, 1, 9-20.

County Development Strategy of Osijek-Baranja County 2011-2013. 2011. Osijek. (in Croatian)

Croatia - UNESCO World Heritage Centre. URL:http://whc.unesco.org/en/statesparties/hr. 13/12/2011.

Cućić, D., Frajman-Jakšić, A., Nater, N. 2007. The Role of Nature Park "Kopački rit" in strengthening competitiveness and regional prosperity of Osijek-Baranja County. Proceedings "Knowledge and Competitiveness", Juraj Dobrila University, Pula, 453-479. (in Croatian with English summary)
Damjanović, D. 2009. Đakovo Cathedral. Matica Hrvatska, Zagreb, 458 pp. (in Croatian with English summary)

Danube limes in Croatia. URL: http://www.dunavskilimes-amo.com.hr/index.html. 13/12/2011.

Development strategy of Vukovar-Srijem County 2011-2013. 2011. Institute for International Relations (IMO), Zagreb; Development Agency of Vukovar-Srijem County HRAST d.o.o., Vukovar. URL: http://www.vukovarsko-srijemska-zupanija.com/ upload/paragrafi_upload/2011-7-6_2836819_ZRSVSZ-Final.pdf. 19/12/2011. (in Croatian)

Duhr, S. 2011. Baltic Sea, Danube and Macro-Regional Strategies: A Model for Transnational Cooperation in the EU?. Notre Europe, Paris, 54 pp.

Europa. EUR-Lex Home. Commission Communication - EU Strategy for the Danube Region. URL: http://eur-lex.europa.eu/LexUriServ/LexUriServ. do? uri=CELEX:52010DCo715:EN:NOT. 12/12/2011.

European Commission. Commission Staff Working Document. Action Plan. Accompanying document to the communication From the Commission to the European Parliament, the Council, the European Economic and Social Committee and the Committee of the Regions. European Union Strategy for the Danube Region. URL: http://www.danubestrategy.eu/fileadmin/danube/media/EUSDR_action_ plan_danube.pdf. 12/12/2011.

European Commission. Regional Policy - Inforegio. EU Strategy for the Danube Region. Priority Areas. URL: http://ec.europa.eu/regional_policy/cooperate/danube/priority_en.cfm. 12/12/2011.

European Commission. Regional Policy - Inforegio. EU Strategy for the Danube Region. What's the issue?. URL: http://ec.europa.eu/regional_policy/cooperate/danube/index_en.cfm\#1. 12/12/2011.

EuroVelo 6. URL: http://www.eurovelo6.org/. 13/12/2011.

Giffinger, R., Suitner, J. 2010. Danube Region Strategy - Arguments for a Territorial Capital Based Multilevel Approach. SPATIUM International Review 23, 9-16.

Government of the Republic of Croatia. Sessions and decisions of the Government of the Republic of Croatia. 96th Session of the Government of the Republic of Croatia. URL: http://www.vlada.hr/ naslovnica/sjednice_i_odluke_vlade_rh/2010/96_ sjednica_vlade_republike_hrvatske. 12/12/2011.

Information on the state and tourism development opportunities in the Osijek-Baranja County and the activities of County Tourist Board. 2011. Osijek. URL: http://www.obz.hr/hr/pdf/gospodarstvo/2010/ Infor macija\%200\%2ostanju\%2 oi \% 2orazvojnim\%2omogu\%C4\%87nostima\%2oturizma\%20 na\%2 op odru\%C4\%8Dju\%2o Osje \%C4\%8Dko- 
baranjske\% $20 \% \mathrm{C}_{5} \% \mathrm{BEupanije} \% 2$ oi $\% 20$ radu\%2oTuristi\%C4\%8Dke\%2ozajednice\%20 $\%$ C5\%BDupanije.pdf. 25/12/2011. (in Croatian)

Mišćin, L., Mađer, B. 2008. Current state of tourism in Croatian rural areas in 2008. Tourism Sector Croatian Chamber of Commerce, Zagreb. URL: http:// hgk.biznet.hr/hgk/fileovi/13081.ppt. 19/12/2011. (in Croatian)

Official web site of Vukovar-Srijem County. Working Community of Danube Regions. URL: http:// www.vukovarsko-srijemska-zupanija.com/vsz. php?stranica $=114 \cdot 13 / 12 / 2011$. (in Croatian)

"Osijek-Baranja County in the context of the Danube Strategy". Presentation held on local event "Open Days 2010" in Osijek, October 10, 2010. URL: http://www.slavonija.hr/images/Dokumenti2010/hr/Osje\%C4\%8Dko\%20-\%2obaranjska\%20 \%C5\%BEupanija\%20u\%2okontekstu\%2oDunavske\%20strategije.ppt. 13/12/2011. (in Croatian)

Republic of Croatia. Ministry of Culture. Cultural heritage. Danube - way of culture. URL: http://www. min-kulture.hr/default.aspx?id=1717. 13/12/2011. (in Croatian)

Republic of Croatia. Ministry of Culture. Projects of the Ministry. Project „Vukovar-VučedolIlok“. URL: http://www.min-kulture.hr/default. aspx?ID=100. 13/12/2011. (in Croatian)

Republic of Croatia. Ministry of Tourism. Statistics. Tourism 2010 - short overview. URL: http://www. mint.hr/UserDocsImages/turizam-2010-info.pdf. 17/12/2011. (in Croatian)

Republic of Croatia. Ministry of Tourism. Statistics. 2011. Tourist traffic in September and in the first nine months. URL: http://www.mint.hr/ UserDocsImages/111104-1-9-stat.pdf. 19/12/2011. (in Croatian)

Schymik, C. 2011. Blueprint for a Macro-Region. EU Strategies for the Baltic Sea and Danube Regions, Stiftung Wissenschaft und Politik. German Institute for International and Security Affairs, Berlin, 31 pp.
Strategy for development of Croatian tourism to 2010. 2003. Ministry of Tourism of Republic of Croatia, Zagreb. URL: http://www.mint.hr/UserDocsImages/Strategija\%2ohrvatskog\%2oturizma\%20-\%2ofinalna\%2overzija.pdf. 25/12/2011. (in Croatian)

Šćitaroci, M. O. 2001. Castles and parks in Slavonia - from Zagreb to Ilok, Šćitaroci d.o.o., Zagreb, 380 pp. (in Croatian with English summary)

Tourism in 2010. Statistics reports. 2011. Croatian Bureau of Statistics, Zagreb. (in Croatian)

Transnational Strategy for the Sustainable Territorial Development of the Danube Area with a Focus on Tourism DATOURWAY. National Study - Croatia. 2010. Zagreb. URL: http://www.datourway.eu/ documents/88-701-8910-dat_cro_wp3_analysis_ en.pdf. 19/12/2011.(in Croatian)

UNESCO. Culture. Intangible Heritage. Spring procession of Ljelje/Kraljice (Queens) from Gorjani. URL: http://www.unesco.org/culture/ich/index. php?lg=en\&pg=00011\&RL=00235. 26/12/2011.

UNESCO. Culture. World Heritage Centre. The List. Global Strategy. Tentative lists. Frontiers of the Roman Empire Croatian Limes. URL: http://whc.unesco.org/en/tentativelists/2014/. 27/12/2011.

UNESCO. Culture. World Heritage Centre. The List. Global Strategy. Tentative lists. HistoricalTown Planning Ensemble Tvrda (Fort) in Osijek. URL: http://whc.unesco.org/en/tentativelists/161/. 27/12/2011.

„Vukovar-Srijem County in the context of the Danube Strategy". Presentation held on local event „Open Days 2010“ in Osijek, October 10, 2010. URL: http://www.slavonija.hr/images/Dokumenti2010/hr/Vukovarsko\%20-\%2osrijemska\%20 \% 5 \%BEupanija\%2ou\%20\%2okontektsu\%2oDunavske\%2ostrategije.ppt. 13/12/2011. (in Croatian)

Wine-tourist roads of the Osijek-Baranja County. 2011. Osijek. URL: http://www.tzosbarzup.hr/UserFiles/ File/pdf/broshura_gotovo_2.pdf. 19/12/2011. (in Croatian) 